\title{
Agriculture and emigration: A case study of Manapang Village, Tanahun, Nepal
}

\author{
U. Khanal ${ }^{1 *}$, R.C. Khanal ${ }^{2}$, P.P. Regmi ${ }^{3}$ \\ ${ }^{1}$ Local Initiatives for Biodiversity, Research and Development, Pokhara, Nepal \\ ${ }^{2}$ Department of Food Science, University of Arkansas, Fayetteville, AR, USA \\ ${ }^{3}$ Institute of Agriculture and Animal Science, Rampur Campus, Chitwan, Nepal
}

\begin{abstract}
A study was undertaken to assess the relationship between agriculture and emigration in Manapang Village Development Committee (VDC) of Tanahun District, Nepal. A total of 120 randomly sampled households were interviewed using a semi-structured questionnaire. Results showed that the average land holding size, irrigated land holding size, livestock holding, income from agriculture, and investment of household income in agriculture were found to be higher in non-migrating households than in migrating households, whereas total household income was higher in migrating households than in non-migrating ones. The marginal value productivity of labor was lower for major crops than that of average wage rate from non-farm work. The size of abandoned land was higher in migrating than non-migrating households. The average share of remittances in household income was $62.50 \%$ in migrating household. Higher share of the remittances was used for consumption purposes, but only $5 \%$ was used in agriculture. Findings revealed that although emigration has a positive effect on the overall economy in the rural households, however, agricultural productivity is suffered.
\end{abstract}

Key words: Household income, Labor force, Livelihood, Remittances

\section{Introduction}

Emigration from hills and mountains to the Terai plains and other areas in search of better opportunities is a common phenomenon in Nepal. It has been estimated that more than a million people from the mountain and hilly areas have migrated (CBS, 2002). The same study shows a internal migration from the hills to urban areas have increased steadily over time from $13.4 \%$ in 1971 to $16.3 \%$ in 1981 to $17.2 \%$ in 1991 to $26.8 \%$ in 2001 (CBS, 2002). Emigration of Nepali people abroad is also not a new phenomenon that started as far back as 200 years ago and remittances have been sent regularly, continuously, and systematically over the years to support the families back home (Gurung, 2004). The 1952/54 census enumerated 198,130 persons or $2.3 \%$ of the total population being absent from the country for more than 6 months and living abroad. Of this absentee population, $97.3 \%$ were originally from the mountains and hills of Nepal (K.C., 2003). This flow of emigration increased to 328,470 (3.4\%) in 1961, 402,977 (2.7\%) in 1981, 656,290 (3.7\%) in 1991 and 762,181 (3.4\%) in 2001 (CBS, 2002). According to

*Corresponding author, email address: khanal_uttam2@yahoo.com
Nepal Living Standard Survey, 23 \% of households in Nepal received remittances in 1995 and that proportion climbed to about $32 \%$ in 2004 . The amount of remittances also increased from about NRs. 22,000, or $36 \%$ of mean household yearly consumption expenditure in 1995, to NRs. 35,000 or $44 \%$ of mean expenditure in 2004 (Michael et al., 2007).

Emigration from hills and mountains has led to both positive and negative social and economic implications for the place of origin. The loss of family labor due to emigration can be offset by the income gains derived from migrants' remittances. However, members in these households may decide to reduce the amount of work needed in their traditional occupations and instead, increase leisure time as a result of higher income from remittances. This may be particularly true for low-return and less attractive types of manual work in agriculture. This has deleterious impact of remittances on agricultural productivity and food production both at the household as well as at the country level. While, there has been a constant emigration of people from the hilly and mountainous areas of Nepal to other places, including abroad, for more than two centuries. Its overall 
impact at the local level, more importantly on agriculture has not been investigated systematically. Therefore, a case study about the relationship between emigration and agriculture was undertaken involving a typical village that has both agriculture and emigration at the heart of its survival

\section{Materials and Methods}

Survey Research Design was used to conduct the research study. Manapang Village Development Committee (VDC) of Tanahun District in the western mid hills of Nepal was purposefully selected for the study. The Manapang VDC represented occupation of people in both traditional agriculture as well as their emigration for greener pastures. While, agriculture still remains the primary occupation of a majority of the people, where emigration has also become a prominent factor in the VDC. The households who have members migrated outside the home District of Tanahun and remained at least six months outside their home were considered the migrating households. The sampling frame consisted of 986 migrating households and 538 non-migrating households as sampling unit. Altogether 120 households, 80 from migrating and 40 from non-migrating households were selected randomly using random number table. Semistructured questionnaires for migrating and non-migrating household were prepared to collect information at the household level. In addition to the semi-structured questionnaire, checklists were prepared to collect information through group discussion and key informants survey. Secondary data were also collected both published and unpublished sources as well as the internet.

Cobb-Douglas production function was used to estimate the response of factor of production, specially the labor on different crops. Cobb Douglas production function, in its stochastic form is expressed as,

$$
\begin{aligned}
& \mathrm{Y}=\beta_{0} \mathrm{~L}^{\beta 1} \mathrm{~K}^{\beta 2} \mathrm{e}^{\mu} \\
& \text { Where, } \mathrm{Y}=\text { output } \\
& \mathrm{L}=\text { labor } \\
& \mathrm{K}=\text { capital } \\
& \mu=\text { stochastic disturbance term } \\
& \mathrm{e}=\text { base of natural logarithm }
\end{aligned}
$$

In the form of log-transformation, the following equation can be obtained,

$$
\ln Y=\ln \beta_{0}+\beta_{1} \ln \mathrm{L}+\beta_{2} \ln \mathrm{K}+\mu
$$

The following model was used in the study.

$\ln Y=\ln \beta_{0}+\beta_{1} \ln \mathrm{la}+\beta_{2} \ln \mathrm{fm}+\beta_{3} \ln \mathrm{cf}$

Where, $\mathrm{Y}=$ yield $(\mathrm{kg} / \mathrm{ha})$

$\beta_{0}=$ constant and $\beta_{1}$ is the exponent of labor, $\beta_{2}$ is the exponent of farmyard manure and $\beta_{3}$ is the exponent of chemical fertilizer.

$$
\begin{aligned}
& \mathrm{La}=\text { labor }(\mathrm{man} \text { day/ha) } \\
& \mathrm{Fm}=\text { farmyard manure }(\mathrm{kg} / \mathrm{ha}) \\
& \mathrm{Cf}=\text { chemical fertilizer }(\mathrm{kg} / \mathrm{ha})
\end{aligned}
$$

Yield per ha was taken as dependent variable and labor, farmyard manure and chemical fertilizer as independent variables.

Physical marginal productivity of labor, farmyard manure and chemical fertilizer was calculated based on the coefficient value of each parameter derived from regression. These values were calculated using the following equation (Koutsoyiannis, 1975),

$$
\begin{aligned}
& \mathrm{MP}_{\mathrm{la}}=\mathrm{b}_{1} \cdot \mathrm{Y} / \mathrm{L}=\mathrm{b}_{1}\left(\mathrm{AP}_{\mathrm{la}}\right) \\
& \mathrm{MP}_{\mathrm{fm}}=\mathrm{b}_{2} \cdot \mathrm{Y} / \mathrm{L}=\mathrm{b}_{2}\left(\mathrm{AP}_{\mathrm{fm}}\right) \\
& \mathrm{MP}_{\mathrm{cf}}=\mathrm{b}_{3} \mathrm{Y} / \mathrm{L}=\mathrm{b}_{3}\left(\mathrm{AP}_{\mathrm{cf}}\right)
\end{aligned}
$$

Where,

$$
\begin{aligned}
& \mathrm{MP}_{\mathrm{la}}=\text { Marginal productivity of labor } \\
& \mathrm{MP}_{\mathrm{fm}}=\text { Marginal productivity of farmyard manure } \\
& \mathrm{MP}_{\mathrm{cf}}=\text { Marginal productivity of chemical fertilizer } \\
& \left(\mathrm{AP}_{\mathrm{la}}\right)=\text { Average productivity of labor } \\
& \left(\mathrm{AP}_{\mathrm{fm}}\right)=\text { Average productivity of farm yard manure } \\
& \left(\mathrm{AP}_{\mathrm{cf}}\right)=\text { Average productivity of chemical fertilizer } \\
& \mathrm{b}_{1} \mathrm{~b}_{2} \mathrm{~b}_{3}=\text { Coefficients of respective parameters }
\end{aligned}
$$

\section{Results and Discussion}

The total population of the sampled households, which included both migrating and non-migrating households, was 810 (Table 1). 
Table 1 Population distribution of the households surveyed (Figures in parentheses indicate the percentage of respective category)

\begin{tabular}{lcccc}
\hline Household category & Male & Female & Total & Average Family size \\
\hline Migrating & $283(49.05)$ & $294(50.95)$ & $577(100.00)$ & 7.21 \\
Non-migrating & $115(49.36)$ & $118(50.64)$ & $233(100.00)$ & 5.83 \\
Overall & $398(49.14)$ & $412(50.86)$ & $810(100.00)$ & 6.75 \\
\hline
\end{tabular}

The average family size was higher in migrating households (7.21) than in non-migrating households (5.83). The sample population (Table 2) was dominated by Janajati (certain ethnic groups defined officially), both in migrating (53.7\%) and non-migrating households (32.5\%).

More than half of the population (56.54\%) was of economically active age (Table 3). This was found higher in migrating $(58.23 \%)$ than in non-migrating $(52.36 \%)$ pool. During field study it was observed that most of the respondents were females (i.e. $61.67 \%$ ) across the study sites. This could be due to the emigration of a higher number of male members of the household than their female counterparts.
The average land holding size of migrating households (0.77 ha) was lower, whereas that of non-migrating ( $0.86 \mathrm{ha})$ households was higher (Table 4) than the national average of 0.8 ha (MOAC, 2009).

Land sharing-out process, a practice very common in Nepali agriculture, was higher in migrating (48.75\%) than in nonmigrating households (17.5\%). Sharing-out the tillable land by migrating households might be due to the scarcity of agriculture labor for farming. Land sharing-in process (Table 5) was seen more in non-migrating households (35.0\%) than migrating households (18.75\%).

Table 2 Ethnic composition of the households surveyed (Figures in parentheses indicate the percentage of respective category)

\begin{tabular}{lccr}
\hline Ethnicity & Migrating & Non-Migrating & Total \\
\hline Brahmin & $9(11.25)$ & $12(30.00)$ & $21(17.50)$ \\
Chhetri & $10(12.50)$ & $9(22.50)$ & $19(15.83)$ \\
Janajati & $43(53.70)$ & $13(32.50)$ & $56(46.67)$ \\
Dalit & $18(22.50)$ & $6(15.00)$ & $24(20.00)$ \\
\hline Total & $80(100)$ & $40(100)$ & $120(100)$ \\
\hline
\end{tabular}

Table 3 Age distribution by households category (Figures in parentheses indicate the percentage of respective category)

\begin{tabular}{lccr}
\hline Age group & Migrating & Non-Migrating & Total \\
\hline$<15$ & $178(30.85)$ & $84(36.05)$ & $262(32.35)$ \\
$15-59$ & $336(58.23)$ & $122(52.36)$ & $458(56.54)$ \\
$>59$ & $63(10.92)$ & $27(11.59)$ & $90(11.11)$ \\
\hline Total & $577(100.00)$ & $227(100.00)$ & $810(100.00)$ \\
\hline
\end{tabular}

Table 4 Land holding by household category

\begin{tabular}{lccr}
\hline & Household category & Mean & SDEV \\
\hline Total land, ha & Migrating & 0.77 & 0.55 \\
& Non-migrating & 0.86 & 0.53 \\
Khet (Irrigated), ha & Migrating & 0.21 & 0.19 \\
& Non-migrating & 0.43 & 0.29 \\
\hline
\end{tabular}

Total land holding: $t$-value: -0.895 at d.f.: 118 ( $P$ value: 0.373$)$

Irrigated land holding: $t$-value: -5.060 at d.f.: 118 ( $P$ value: 0.00$)$ 
Table 5 Land holding pattern by household category (Figure in parentheses indicate the percentage of respective category)

\begin{tabular}{llcr}
\hline Pattern & \multicolumn{2}{c}{ Sampled households (No.) } & Total \\
\hline & \multicolumn{1}{c}{ Migrating } & Non-migrating & \\
\cline { 2 - 4 } Own land & $26(32.50)$ & $19(47.50)$ & $45(37.50)$ \\
\hline Shared-in & $15(18.75)$ & $14(35.00)$ & $29(24.17)$ \\
Shared-out & $39(48.75)$ & $7(17.50)$ & $46(38.33)$ \\
\hline Total & $80(100.00)$ & $40(100.00)$ & $120(100.00)$ \\
\hline
\end{tabular}

Traditionally males are more responsible for managing the overall agriculture than females in the western mid-hills. When male members emigrate, certain degree of void may have occurred and hence, sharing-out of land. Corollary to it would be the sharing-in of their land by the non-migrating households, where male members are still tilling the land.

\section{Marginal value productivity of labor}

Since rice, wheat, maize, and millet are the major crops grown in the region, they were used to find the marginal value productivity of labor in agriculture. Along with the labor, two other inputs, farmyard manure and chemical fertilizer were also used in the model. The three inputs namely labor, farmyard manure, and chemical fertilizer in combination explain about $46 \%$ of the total variance of productivity of paddy, $53 \%$ of maize, $52 \%$ of wheat and $63 \%$ of millet as indicated by $R^{2}$ (Table 6). The response of farm yard manure as shown by the results of Cobb-Douglas function is negative in paddy, which was not expected. Such an inconsistent response is mainly because farmyard manure is not commonly used in paddy fields in the hills, and whenever it is used, the amount is rather low. The two inputs labor and chemical fertilizers had significant positive response in all the major crops grown in the region. The response of labor is comparatively very high as indicated by the standardized beta coefficients, 0.527, 0.514, 0.597, and 0.691 for paddy, maize, wheat, and millet, respectively.

Table 6 Production function and elasticity of different crops

\begin{tabular}{|c|c|c|c|c|}
\hline Statistics & Paddy & Maize & Wheat & Millet \\
\hline Number of observation & 78 & 43 & 38 & 45 \\
\hline$R^{2}$ & 0.458 & 0.529 & 0.515 & 0.627 \\
\hline Adjusted $R^{2}$ & 0.452 & 0.524 & 0.591 & 0.44 \\
\hline$F$ & 45.30 & 21.44 & 32.54 & 20.15 \\
\hline Significance & 0 & 0 & 0 & 0 \\
\hline (Constant) & 3.948 & 3.116 & 2.223 & 2.531 \\
\hline$T$ & 13.93 & 5.51 & 6.45 & 10.05 \\
\hline Significance & 0 & 0 & 0 & 0 \\
\hline Labor & 0.55 & 0.48 & 0.41 & 0.63 \\
\hline$T$ & 10.13 & 4.23 & 5.21 & 5.93 \\
\hline Significance & 0 & 0 & 0 & 0 \\
\hline Farmyard manure & -0.014 & 0.223 & 0.182 & 0.020 \\
\hline$T$ & -1.093 & 2.106 & 2.691 & 0.753 \\
\hline Significance & 0.278 & 0.042 & 0.019 & 0.456 \\
\hline Chemical fertilizer & 0.79 & 0.302 & 0.246 & 0.196 \\
\hline$T$ & 2.660 & 2.082 & 2.727 & 1.109 \\
\hline Significance & 0.010 & 0.044 & 0.017 & 0.274 \\
\hline \multicolumn{5}{|l|}{ Standardized coefficients } \\
\hline Labor & 0.527 & 0.514 & 0.597 & 0.691 \\
\hline Farmyard manure & -0.078 & 0.253 & 0.294 & 0.078 \\
\hline Chemical fertilizer & 0.186 & 0.220 & 0.286 & 0.131 \\
\hline \multicolumn{5}{|l|}{ Descriptive statistics } \\
\hline Production (kg/ha) & 2014.5 & 1069.2 & 904.2 & 1076.7 \\
\hline Labor use (man-day/ha) & 202.0 & 118.5 & 88.5 & 151.8 \\
\hline Organic manure use (kg/ha) & 2717.4 & 9318.4 & 4975.0 & 425.4 \\
\hline Chemical fertilizer (kg/ha) & 22.4 & 5.39 & 28.5 & 1.35 \\
\hline
\end{tabular}


The physical marginal productivity of labor is $5.48 \mathrm{~kg}$ for paddy, $4.32 \mathrm{~kg}$ for maize, $4.15 \mathrm{~kg}$ for wheat and $4.43 \mathrm{~kg}$ for millet (Table 7). The marginal value productivity of labor in agriculture, which was obtained by multiplying the price of respective crop, is Rs 88.33 for paddy, Rs 65.14 for maize, Rs 63.87 for wheat and Rs 66.84 for millet. the total cultivable land have been left fallow for more than a year. One of the reasons for the increasing proportion of abandoned land in the region is the unwillingness of people to bring their land into cultivation because the return from these crops is lower compared to the non-farm wage rate.

Table 7 Physical marginal productivity of factor input for major crops

\begin{tabular}{lcccc}
\hline Marginal productivity & Paddy & Maize & Wheat & Millet \\
\hline a. Physical marginal productivity (kg) & 5.48 & & & 4.43 \\
Labor & -0.0103 & 4.32 & 4.15 & 0.0506 \\
Farmyard manure & 71.2 & 0.0256 & 0.033 & 156.3 \\
Chemical fertilizer & 59.9 & 7.82 & 66.8 \\
b. Marginal value productivity & Rs) & & & 0.746 \\
Labor & 88.3 & 65.1 & 63.9 & 2359.6 \\
Farmyard manure & -0.166 & 0.386 & 0.508 & 120.3 \\
Chemical fertilizer & 1147.3 & 4.05 & & \\
\hline
\end{tabular}

The average wage rate from non-farm work is Rs. 120. So, the non-farm wage rate is much higher than the price of the marginal productivity of labor. Because of such differences in the wage rate and the marginal productivity of labor in agricultural crops, there has been a rather high flow of labor from rural to other areas more recently. The increasing percentage of the absentee population from rural areas is also a reflection of such a phenomenon (Khanal \& Watanabe, 2006).

\section{Abandonment of crop land}

The proportion of abandoned land has been increasing in the region. The household survey result shows that 19.13\% of total land owned by farm household was abandoned (Table 8). The percentage of abandoned land was $26.73 \%$ in migrating households and $12.36 \%$ in non-migrating households.

A large proportion of abandoned land was owned by families migrated permanently to other areas. It was not possible to include these household in the sample for household survey. During group discussion it was reported that about 30\% of
This further creates a situation where agriculture is perceived, and rightly so, unproductive and/or less attractive making the situation conducive for emigration.

The average size of abandoned land was found significantly higher ( $P$-value 0.006$)$ in migrating households ( $0.21 \mathrm{ha})$ than that of non-migrating households (0.12 ha). When privately held land use pattern was analyzed, non-migrating families had a higher proportion of Khet, the irrigated land traditionally used for paddy cultivation, than migrating families, whereas migrating families had a higher proportion of Bari, the rain fed land used primarily for maize, millet, and other cereal grains (Fig. 1).

Moreover, greater ownership of Khet (or production of rice by corollary) also indicates a greater security and wealth in these hilly areas, which may actually be one of the reasons behind the emigration of these families to other areas in search of a better future for themselves and their families.

Table 8 Land abandonment by household category

\begin{tabular}{lcccc}
\hline Household category & \multicolumn{3}{c}{ Abandoned land (ha) } \\
\cline { 2 - 4 } & Minimum & Maximum & Mean & SDEV \\
Migrating & 0.00 & 0.75 & 0.21 & 0.201 \\
Non-migrating & 0.00 & 0.52 & 0.17 & 0.143 \\
\hline
\end{tabular}

$t$ - value: 2.776 at df 114 ( $P$ value : 0.006$)$ 


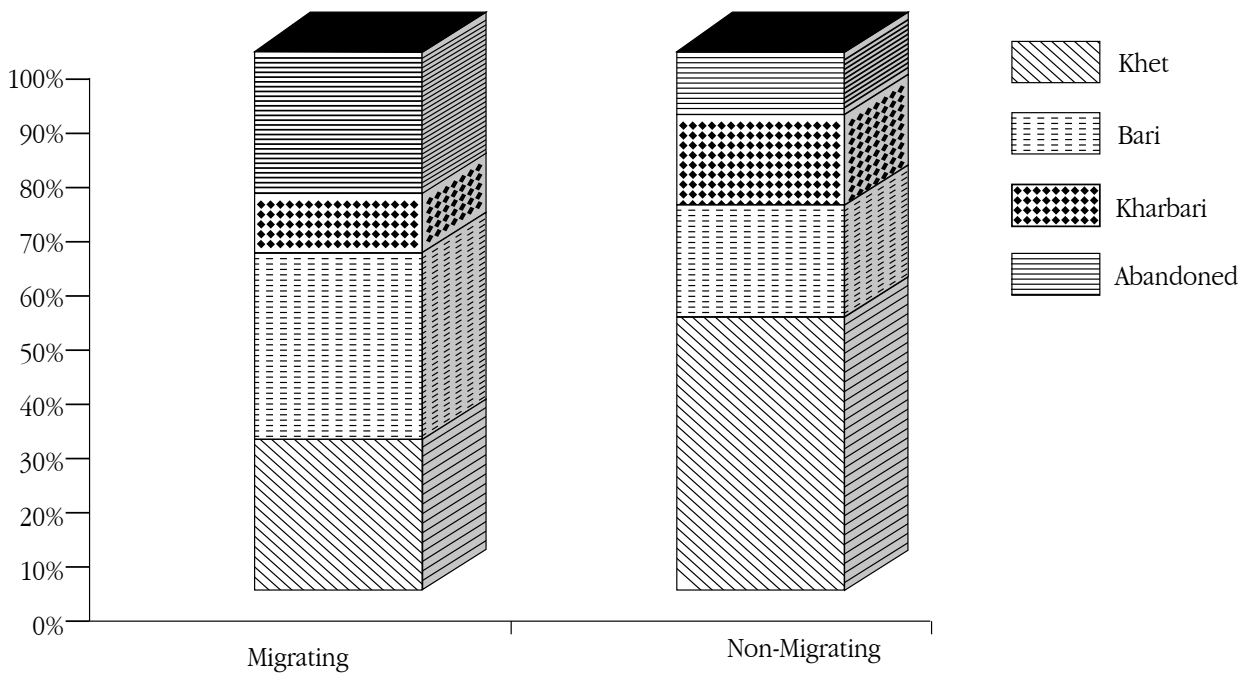

Fig. 1 Privately held land use pattern. Khet - irrigated land traditionally set aside for paddy cultivation, Bari - rain fed land used for culti vating other cereals, such as maize, corn, etc., Kharbari - marginal land pri marily used for growing thatch grass and forage for livestock

\section{Livestock holding}

Livestock holding shows the picture about farmers' economic condition and it also gives the idea about the total farm yard manure available in the households. The number of livestock was obtained from migrating households before and after the migration and also from the non-migrating household. Since different livestock species were raised in the study area, a common unit i.e. Livestock Unit was used to convert all the livestock species in a single unit. The aggregated LSUwas calculated as explained by Adhikari (2000).

$\mathrm{LSU}=1.5$ (number of buffalo) +1 (number of cow/bull) +0.6 (number of swine/pig) +0.4 (number of sheep/goat) +0.2 (number of poultry)
The survey result shows that there was marked difference in livestock numbers before and after the migration of family members (Table 9). Livestock holding was higher before the migration of family members (8.59 LSU) compared to after migration (5.42 LSU). Similarly, at present the number of livestock was higher in non-migrating household (7.31 LSU) as compared to migrating households. The size of the herd (in LSU) was significantly different before and after the migration and between migrating and non-migrating households at present.

Table 9 Distribution of livestock ownership by household category

\begin{tabular}{lcccr}
\hline \multirow{2}{*}{ Household category } & \multicolumn{3}{c}{ Livestock ownership (Livestock Standard Unit*) } & SDEV \\
\cline { 2 - 4 } & Minimum & Maximum & Mean & 3.04 \\
Migrating (Before) & 0 & 17.30 & 8.59 & 2.53 \\
Migrating (After) & 1.50 & 13.00 & 5.42 & 2.37 \\
Non-migrating & 2.0 & 10.90 & 7.31 & \\
\hline
\end{tabular}

$t$-value: -3.898 at d.f. : 114 ( $P$ value : 0.00$)$ migrating and non-migrating

$t$-value : -8.889 at d.f. : $75(P$ value :.000) before and after

*Livestock Standard Unit $=1.5$ (number of buffalo) +1 (number of cow/bull) +0.6 (number of swine/pig) +0.4 (number of sheep/goat) +0.2 (number of poultry) (Adhikari, 2000) 


\section{Household income and its investment}

The average share of remittances in household income among households with migrants is $62.50 \%$. The total household income was found significantly higher in migrating households (NRs. 133,281) than that of non-migrating households (NRs. 108,815). While comparing income from agriculture, it was significantly higher in non-migrating households than in migrating households ( $\boldsymbol{P}$-value 0.000) The details of the income comparison between migrating and non-migrating household have been shown in the (Table 10).

Table 11 shows the investment pattern of household income by respondent category. The findings revealed that the large proportion of the income was spent in food and clothing in both migrating (42.86\%) and non-migrating (38.12\%) households. However, investment in food and clothing was higher in migrating household than non-migrating ones.

Investment in education, food and cloth, and purchase of land as well as construction and improvement of houses was significantly higher in migrating households than in

Table 10 Income comparison by household category

\begin{tabular}{lcc}
\hline Household income & Mean & SDEV \\
\hline Total income & & \\
$\quad$ a. Migrating & 133281 & 48621.2 \\
$\quad$ b. Non-migrating & 108815 & 46012.0 \\
Income from agriculture & & \\
$\quad$ a. Migrating & 29650 & 14815.4 \\
b. Non-migrating & 42700 & 21302.1 \\
\hline
\end{tabular}

non-migrating households, whereas investment in agriculture and social functions was significantly higher in non-migrating households than in migrating households.

\section{Remittance use}

The use of remittances (Fig. 2) was categorized into six major groups namely, education and health, food and cloth, agriculture (purchase of equipments, inputs, animals, labor, land improvements, etc.), repayment of loan incurred for and during emigration, land purchase and construction of new or improvement of old houses, and others which included festivals, ceremonies, purchase of jewelries, etc.

It is obvious from the figure that a large share of the remittances was used for food and clothing purpose (36\%) followed by education and health (18\%), repayment of loan during departure (18\%), others (13\%). Purchasing the land and improvement of the existing or construction of new houses was at $10 \%$ of the income with only $5 \%$ going for agricultural purposes.
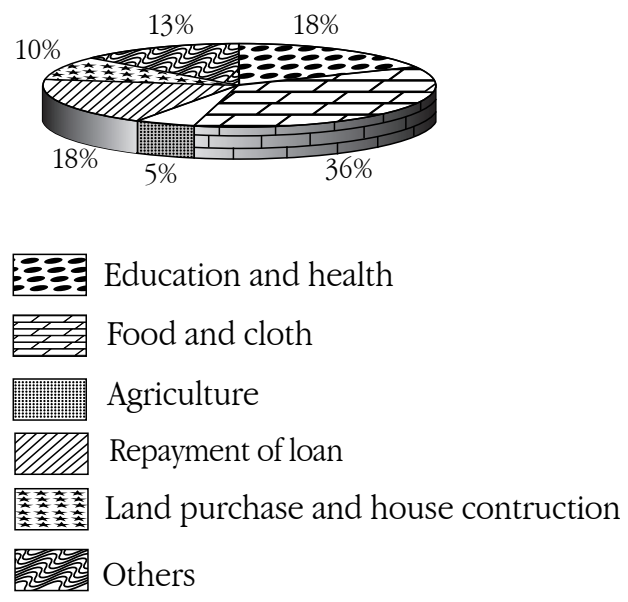

Fig. 2 Use of remittance money by households in Manapang Village, Tanahun, Nepal

Table 11 Investment of household income

\begin{tabular}{lcccr}
\hline Variables & Migrating & Non-migrating & $\boldsymbol{t}$-value & $\boldsymbol{P}$-value \\
\hline Education & 21.43 & 14.22 & 15.884 & 0.000 \\
Food and cloth & 42.86 & 38.12 & 2.531 & 0.025 \\
Health & 4.07 & 3.33 & 1.488 & 0.161 \\
Agriculture & 9.68 & 26.46 & -21.343 & 0.000 \\
Land purchase, and construction & & & & 0.000 \\
and improvement of houses & 14.19 & 8.63 & 5.620 & 0.000 \\
Social functions & 4.23 & 6.89 & -5.349 & 0.027 \\
Other & 3.59 & 2.35 & 2.494 & \\
Total & 100 & 100 & & \\
\hline
\end{tabular}




\section{Conclusion}

Agriculture is the largest form of land use in Nepal. Agriculture dominates the rural economy and is often the only source of employment for rural people. The decreasing relative importance of the agricultural sector is a pervasive phenomenon of economic development, which often entails sizeable population movements out of rural areas. Emigration of household members leads to a decline in the amount of labor available to the household. Majority of the economically active male population were found to be outside the village. The marginal value productivity of labor in agriculture was found less than the wage rate from non-farm work. This might be the reason for high rate of labor migration from rural areas recently. Agricultural productivity has decreased in the village because of reduced quantity of manure. Due to the lack of labor force i.e. active male, the size of livestock holding also decreased in the village. People were not interested in cultivating their limited and less fertile land. As a result, the proportion of abandoned land in the area has increased over the years.

The total household income was higher in migrating households than that of non-migrating households, but income from agriculture was higher in non-migrating households than in migrating households. The contribution of remittance in household income among migrating households was more than fifty percent. Investment of household income in agriculture was higher in non-migrating households than in migrating households. Only a small proportion of remittance was used for agriculture purposes. Whatever a migrant earns, it goes for daily household's needs and family expenses. Most of the migrants would have already sold or mortgaged some or all, depending on individual needs, of their land to pay for the foreign employment. In other cases, it was abandoned for the lack of family members to till the land. As a result, only a small proportion of remittance income was used for agricultural purposes. Thus, on the one hand, agricultural land was neglected and food was consumed from the market and on the other hand, income was spent on consumption materials, which ultimately creates dependency. No visible improvement has been seen in the agriculture sector as a consequence of emigration. Furthermore, the land that used to be tilled has now been abandoned creating further erosion in the agricultural productivity.

It was also found that many households in the VDC have maintained their good lives even in the village. It shows that utilization of own resources with better management can be a good option to overcome the rural poverty rather than selling or mortgaging their land to landlords to invest for foreign employment. Proper management of local resources can create further employment opportunities in the village. To sum up, whether migration is the development or an indication of increased dependency of rural households on remittance money in Nepal needs further studies and more discussions.

Agriculture in the rural area of Nepal is labor intensive and the yield is highly sensitive to the use of labor and other inputs such as chemical fertilizers, pesticides etc. The marginal value productivity of labor in agriculture is low, which was also true in the current study. Suitable technology and production plan should be generated to increase the marginal productivity of labor, which can reduce shifting of labor from agricultural to non-farm activities. While emigration of people resulted in an increase in the overall household income, it adversely affected the agricultural productivity, which was observed in a large area of cultivable land being abandoned and the increased proportion of such abandoned land. Moreover, increased household income from remittance money was not invested back in agricultural operations, further eroding the productivity. Whether emigration is an indication of the development or an indication of increased dependency of rural households on remittance money in Nepal needs further investigation in a holistic approach, not just the increased household income, but also the erosion in local productivity. Another critical aspect to reduce the emigration pressure and maintain or increase the income would be to develop market-oriented niche based farming systems, such as commercial dairy farming, off-season vegetable farming, fruit farming, agroforestry, etc. on abandoned land. However, effective land use policies are also necessary. A strong technical support system is also necessary for sustainable development of niches based farming and so are market and service infrastructures to reduce transportation cost of inputs and outputs. Consequently, it is suggested to tackle agricultural problems and building social facilities in rural areas may lessen the emigration of people from these areas.

\section{Acknowledgments}

The authors express sincere thanks to Mr. J.P. Dutta and Dr. R.B. Thapa, Institute of Agriculture and Animal Science for their input. Thanks also to Dr. N.R. Khanal and Dr. P.B. Bhandari for their assistance in completing the study. The authors are much obliged to acknowledge Global Future Institute, Dallas, USA, for providing the financial support. Finally, our deep appreciation goes to cooperating households for their participation and cooperation in the survey. 


\section{References}

Adhikari, J. (2000). Decisions for survival: Farm management strategies in the mid hills of Nepal. New Delhi, Adroit publishers.

Bhandari, P. (2004). Relative deprivation and migration in an agricultural setting of Nepal. Population and Environment, 25, 38-53.

CBS (2002). Population census 2001, National report. Kathmandu, Central Bureau of Statistics.

Gurung, M. (2004). Nepal and international labor migration. Kathmandu, Population Student Society of Nepal.

IFAD (2006, December). Nepal country strategic opportunities program. Enabling the rural poor to overcome poverty. International Fund for Agricultural Development. Eighty-ninth Session, Rome.

KC, B.K. (2003). Migration, poverty and development in Nepal. Economic and Social Commission for Asia and the Pacific, Ad Hoc Expert Group Meeting on Migration and Development, Bangkok.

Khanal, N.R., \& Watanabe, T. (2006). Abandonment of agricultural land and its consequences: A case study in the Sikles area, Gundaki basin, Nepal Himalaya.Mountain Research and Development, 26, 32-44.

Koutsoyiannis, A. (1979). Modern microeconomics. Basingstoke, London, Macmillian Education Limited.
Michael, L., Mikhail, B.O., \& Elena, G. (2007). Work-related migration and poverty reduction in Nepal. World Bank Policy Research Working Paper 4231, Washington DC, The World Bank.

MOAC (2009). Selected indicators of Nepalese agriculture and population. Kathmandu, Ministry of Agriculture and Cooperatives. Agribusiness Promotion and Statistics Division and Gender Equity and Environment Division.

Mora, J. (2005, July ). The impact of migration and remittances on distribution and sources of income: The Mexican rural case. United Nations Expert Group Meeting on International Migration and Development, New York. Pun (2007). Determinants of out-migration and its implications in agriculture and housebold economy: a case of Banjbkakani vdc of doti district, Nepal (Master's dissertation). Department of Agricultural Economics, Institute of Agriculture and Animal Science, Tribhuvan University, Rampur Chitwan.

Rozelle, S., Taylor, J.E., \& Debrauw, A. (1999). Migration, remittances and agricultural productivity in China. American Economic Review, 89, 287-291.

Taylor, J., Rozelle, S., \& de Brauw, A. (2003). Migration and incomes in source communities: A new economics of migration perspective from China. Economic Development and Cultural Change, 52, 75-101. 